\title{
PROSES PEMBUATAN GIGI TIRUAN SEBAGIAN LEPASAN DARI BAHAN KOMBINASI LOGAM DAN AKRILIK
}

\author{
Oleh \\ Merry Thressia \\ Staf Pengajar Akademi Teknik Gigi (ATG) Padang.
}

\begin{abstract}
Removable partial dentures (GTSL) is a denture that replaces one or more missing teeth in the maxilla or mandible and open-pairs by patients. Removable partial dentures (GTSL) is part prosthodonsia that replaces one or more missing teeth with artificial teeth that are supported by a combination of gear teeth or mucous mucous installed and removed by the patient. GTSL facilitate users in treatment. To know the process of making GTSL of combination metal and acrylic.

Design of this study is the study of literature, where the author collected some literature studies related to the process of making GTSL of material combination of metal and acrylic. Iini study aims to determine the process of making GTSL of metal and acrylic, then summed up the results of the data obtained.

Results of research on the process of making GTSL of a combination of metal and acrylic material differences at each stage of manufacture, in the process of making metal combinations GTSL more difficult than the stage of manufacture acrylic GTSL. Based on the results of the discussion, it can be concluded that in the process of making GTSL metal and acrylic, researchers must know the good material to use in making dentures, especially for metal framework. GTSL metal combination is stronger than acrylic GTSL and also more costly.
\end{abstract}

Keywords: acrylic, removable partial dentures, prosthodonsia

\begin{abstract}
ABSTRAK
Gigi tiruan sebagian lepasan (GTSL) adalah gigi tiruan yang menggantikan satu atau beberapa gigi yang hilang pada rahang atas atau rahang bawah dan dapat dibuka-pasang oleh pasien. Gigi tiruan sebagian lepasan (GTSL) merupakan bagian prosthodonsia yang menggantikan satu atau beberapa gigi yang hilang dengan gigi tiruan yang di dukung oleh gigi mukosa atau kombinasi gigi mukosa yang dipasang dan dilepas oleh pasien. GTSL mempermudah pemakai dalam perawatannya. Untuk mengetahui proses pembuatan GTSL dari bahan kombinasi logam dan acrylic.

Desain penelitian ini bersifat studi literature, dimana penulis mengumpulkan beberapa studi kepustakaan yang berhubungan dengan proses pembuatan GTSL dari bahan kombinasi logam dan acrylic. Penelitian iini bertujuan untuk mengetahui proses pembuatan GTSL dari bahan logam dan acrylic, kemudian menyimpulkan hasil dari data yang diperoleh.

Hasil penelitian mengenai proses pembuatan GTSL dari bahan kombinasi logam dan acrylic adanya perbedaan pada tiap tahap pembuatannya, dalam proses pembuatan GTSL kombinasi logam lebih sulit dibandingkan dengan tahap pembuatan GTSL acrylic. Berdasarkan hasil pembahasan, maka dapat disimpulkan bahwa dalam proses pembuatan GTSL bahan logam dan acrylic, peneliti harus mengetahui bahan yang baik untuk digunakan dalam membuat protesa gigi, terutama untuk kerangka logam. GTSL kombinasi logam lebih kuat dibanding GTSL acrylic dan juga biayanya lebih mahal.
\end{abstract}

Kata kunci : acrylic, gigi tiruan sebagian lepasan, prosthodonsia

\section{PENDAHULUAN}

Kesehatan secara umum dapat didefinisikan sebagai bentuk perpaduan dari tiga kondisi yang saling terkait satu sama lain, kondisi yang dimaksud adalah fisik, mental, dan sosial. Menurut undang-undang nomor 23 tahun 1992 tentang kesehatan menjelaskan bahwa kesehatan adalah keadaan sejahtera dari badan, jiwa, dan sosial yang memungkinkan setiap orang hidup produktif secara sosial dan ekonomis.

Melayani masyarakat khususnya menyangkut kesehatan gigi dan mulut, dalam hal ini membutuhkan tenaga teknisi gigi yang handal dalam melayani masyarakat sesuai dengan bidangnya. Menurut Menteri 
Kesehatan RI seperti yang tercantum dalam keputusan menteri kesehatan nomor: 372/Menkes/SK/III2007 pada tanggal 27 Maret 2007 bahwa profesi teknisi gigi adalah suatu pekerjaan di bidang keteknisian gigi yang dilaksanakan berdasarkan suatu keilmuan (body of knowledge), memiliki kompetensi yang diperoleh melalui pendidikan yang berjenjang, memalui kode etik yang bersifat melayani masyarakat (Menkes RI, 2007).

Sekarang ini sering ditemukan berbagai permasalahan gigi dan mulut. Diantaranya bau mulut, gigi berlubang, karies gigi, susunan gigi yang tidak teratur dan gigi ompong atau kehilangan gigi. Penyebab kehilangan gigi beragam, di antaranya adalah faktor genetik, faktor penyakit tertentu, faktor lokal dari dalam gigi/ rongga mulut, dan lainnya seperti akibat kecelakaan. Pada faktor lokal dari dalam gigi/ rongga mulut, biasanya terdapat pada gigi yang mengalami karies atau infeksi jaringan gusi akibat aktivitas bakteri, sehingga gigi berlubang dan akhirnya tidak dipertahankan. Karies gigi merupakan salah satu penyebab kehilangan gigi yang sering terjadi pada kaum remaja dan kaum lansia. Karies pada gigi yang tidak dirawat dapat bertambah buruk, sehingga menimbulkan rasa sakit dan berpotensial menyebabkan kehilangan gigi.

Dalam rangka meningkatkan kesehatan gigi dan mulut, pemerintah melalui departemen kesehatan telah melaksanakan berbagai upaya pendekatan pelayanan kesehatan, yaitu pemeliharaan, peningkatan kesehatan (promotif), pencegahan penyakit (preventif), dan penyembuhan penyakit (kuratif) dan pemulihan kesehatan (rehailitatif) yang dilakukan secara menyeluruh, terpadu, dan berkeseimbangan (Herijulianti dkk, 2002).

Gigi tiruan sebagian lepasan (GTSL) merupakan bagian prosthodonsia yang menggantikan satu atau beberapa gigi yang hilang dengan gigi tiruan yang di dukung oleh gigi mukosa atau kombinasi gigi mukosa yang dipasang dan dilepas oleh pasien. GTSL mempermudah pemakai dalam perawatannya. Untuk mengetahui proses pembuatan GTSL dari bahan kombinasi logam dan acrylic.

Gigi tiruan sebagian lepasan (GTSL) adalah gigi tiruan yang menggantikan satu atau beberapa gigi yang hilang pada rahang atas atau rahang bawah dan dapat dibuka-pasang oleh pasien. Berdasarkan bahan dasarnya GTSL ada dua kelompok yaitu GTSL resin akrilik, yaitu gigi tiruan yang basisnya dibuat dari bahan resin akrilik, dan GTSL kerangka logam, yaitu gigi tiruan yang kerangkanya dibuat dari logam. Kedua bahan diatas adalah gigi tiruan yang umum digunakan untuk mengganti kehilangan gigi, sedangkan perbedaannya terletak pada bahan basis yang digunakan untuk mendukung gigi tiruan dan retensi dalam mulut, yang sering menyebabkan ketidaknyamanan pasien saat tersenyum atau berbicara akibat cangkolan yang sering terlihat (Nallaswamy, 2003).

Dari pengamatan penulis, sekarang ini banyak terjadi kehilangan gigi pada masyarakat. Dilihat dari jumlah gigi yang hilang, pada kasus kehilangan sebagian atau keseluruhan gigi dapat dibantu dengan melakukan pembuatan protesa GTSL. Dalam hal pembuatan GTSL dapat menggunakan bermacammacam bahan, yakni akrilik dan logam. GTSL merupakan bagian prosthodonsia yang menggantikan satu atau beberapa gigi yang hilang dengan gigi tiruan dan didukung oleh gigi mukosa atau kominasi gigi mukosa yang dipasang dan dilepas oleh pasien (Academy of Prosthodontics, 1999).

Berdasarkan masalah di atas, maka penulis akan mempelajari bagaimana proses pembuatan gigi tiruan sebagian lepasan dari bahan kombinasi logam dan akrilik. Tujuan akhir dari penelitian ini adalah dapat menambah wawasan dan ilmu pengetahuan tentang proses pembuatan GTSL dari bahan kombinasi logam dan akrilik baik bagi penulis, pembaca dan instansi pendidikan.

\section{BAHAN DAN METODA}

Data yang digunakan dalam penelitian ini berupa studi literatur yang diperoleh penulis dengan mengumpulan data-data yang berhubungan dengan proses pembuatan GTSL yang ditinjau berdasarkan bahan kombinasi logam dan akrilik.

\section{HASIL DAN PEMBAHASAN}

Menurut Rahmadhan tahun 2010, bahan GTSL bahan akrilik merupakan sejenis bahan yang mirip plastik yang keras dan kaku. Bahan ini dipakai untuk plat pada kawat gigi yang bisa dilepas pasang. Biasanya plat gigi tiruan yang terbuat dari akrilik dibuat agak tebal agar plat tidak mudah patah. GTSL bahan akrilik dapat dilihat pada gambar berikut ini:

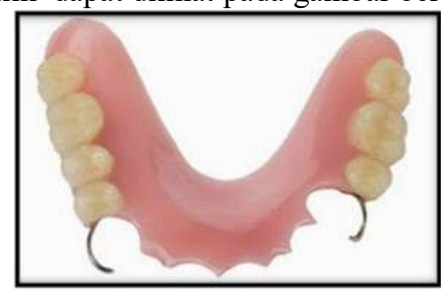

Gambar 1. GTSL akrilik (Mozarta, 2006)

Akrilik adalah rantai polimer terdiri dari unitunit metal metakrilat yang berulang. Akrilik digunakan untuk membuat basis gigi tiruan rehabilitative, untuk plat ortodonsi, maupun resoransi. Keuntungan poli metil metakrilat sebagai bahan basis protesa adalah relatif mudah pengerjaannya. Bahan basis protesa poli metal metakrilat umumnya dikemas dalam bentuk bubuk atau cairan. Cairan mengandung metil metakrilat tidak terpolimer dan bubuk mengandung resain poli 
metil metakrilat pra-polimerisasi dalam bentuk butiran kecil.

Tahapan pembuatan GTSL adalah: Pencetakan rahang, adalah bentuk negatif dari seluruh jaringan pendukung geligi tiruan. Setelah dicor, maka akan didapatkan bentuk positif dari rahang atau model rahang. Desain geligi tiruan, bersihkan model dari sisa-sisa gips dan buat desain geligi tiruan yang akan dibuat, membuat garis median denture out line. Perencanaan dimensi vertical dan oklusi sentries, pasien yang kehilangan sebagian giginya berarti sudah kehilangan bidang oklusi, tinggi gigitan atau dimensi vertical, oklusi sentrik. Ketiga hal ini harus kita cari saat membuat geligi tiruan dengan media tanggul gigitan, galangan gigit atau bagian noklusal bite trim. Memilih gigi, pada kasus pasien ompong, memilih gigi berpedoman pada bentuk wajah, jenis kelamin dan umur pasien untuk menentukan warna dan tingkat keaausanya, sedangkan ukuran gigi disesuaikan dengan garis orientasi pada tangul gigitan. Penyusunan gigi, penyusunan gigi dilakukan diatas malam/ wax. Conturing, setelah bentuk kontur geligi tiruan dipendam dalam kuvet. Packing, proses mencampur monomer dan polimer resin akrilik. Procesing, polimerasi antara monomer yang bereaksi dengan polimernya bila dipanaskan atau ditambahakan zat kimia. Deflasking, bila curing telah selesai, maka flask dibiarkan sampai pada suhu kamar, kemudian flask boleh dibuka. Pemasangan kembali dan pengasahan selektif, pemasangan kembali geligi dalam artikulator bertujuan untuk mengoreksi hubungan oklusi yang tidak harmonis dari geligi tiruan yang baru selesai diproses atau dimasak. Penyelesain geligi tiruan, ini dilakukan dengan cara membuang sisa-sisa resain akrilik pada batas geligi tiruan. Pemolesan geligi tiruan, menghaluskan dan mengkilapkan geligi tiruan tanpa merubah kontur. Uji coba.

Kelebihan bahan akrilik adalah; warna menyerupai gingiva, mudah direparasi bila patah tanpa mengalami ditorsi, mudah dibersihkan, mudah dimanipulasi, kekuatannya baik, harganya terjangkau dan tahan lama, sedangkan kekurangan bahan akrilik adalah; mudah fraktur, menimbulkan porositas, dapat mengalami perubahan bentuk, toleransi terhadap jaringan kurang baik, dapat menimbulkan alergi.

Logam adalah bahan yang tahan terhadap abrasi, sehingga permukaannya tetap licin dan mengkilat, serta tidak menyerap cairan mulut, sehingga sisa makanan sulit melekat dan gigi mudah untuk dibersihkan. Gigi tiruan ini terdiri dari landasan gigi tiruan logam sedangkan gigi buatannya dari bahan akrilik. Karena bahan logam cukup kuat, landasan gigi tiruan kerangka logam dapat dibuat lebih tipis dan lebih kecil, sehingga si pemakai merasa lebih nyaman (Dentamedicacenter.com 2012). GTSL bahan logam dapat dilihat pada gambar berikut ini:

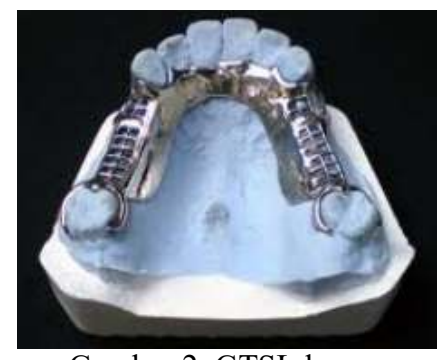

Gambar 2. GTSL logam

GTSL dengan kerangka logam memiliki kualitas mekanik sangat baik dan memberikan kemungkinan desain denture yang mempertimbangkan kesehatan jaringan periodonsium gigi abutment, estetis dan kenyamanan pasien. Hasil ini dapat dicapai dengan membuatdesain kerangka sesederhana mungkin, untuk mengurangi efek negatif dari oral hygiene yang buruk (Rachman, 2007).

Elemen GTSL bahan logam adalah dibuat berdasarkan ruang protesa yang ada, terutama untuk gigi posterior yang ruang protesanya sempit, estetis kurang baik, tahan terhadap daya kunyah yang besar/kuat.

Untuk mengurangi ketebalan dan luasnya landasan, maka dapat digunakan gigi tiruan kerangka logam. Gigi tiruan kerangka logam terdiri dari landasan gigi tiruan dari logam sedang gigi buatannya dari akrilik atau porselen. Karena bahan logam cukup kuat, landasan gigi tiruan kerangka logam dapat dibuat lebih tipis dan lebih kecil, sehingga si pemakai merasa lebih nyaman. Kontak lidah dengan langit-langit tidak terlalu terganggu.

Logam yang digunakan adalah campuran logam khusus yang memerlukan manipulasi lebih rumit, sehingga gigi tiruan ini lebih mahal dari gigi tiruan akrilik. Apabila patah pada bagian logam, tidak dapat disambung seperti akrilik, tetapi harus dibuat ulang. Akan tetapi bila yang patah hanya gigi akriliknya saja, masih dapat disambung/ diganti akriliknya saja. Karena landasan logam harus dicoba dulu ketepatannya sebelum dipasangkan gigi-giginya, maka kunjungan pasien ke dokter gigi lebih banyak dari pemasangan gigi akrilik, karena kekuatan logam, landasan gigi tiruan tidak terlalu terganggu oleh keadaan cairan/ makanan di dalam rongga mulut, yang berpengaruh hanya bagian gigi buatannya saja.

Keuntungan bahan logam adalah dapat mencegah bau tak sedap pada rongga mulut, karena gigi tiruan jenis ini tidak memiliki mikroporus yang dapat menjadi tempat melekatnya plak dan bakteri yang menghasilkan bau mulut, lebih nyaman dipakai (karena dapat dibuat tipis dan sempit), cukup kaku (rigid) walaupun tipis dan sempit, semua bagian gigi tiruan merupakan satu kesatuan dan homogen, disain bagian gigi tiruan dapat dibuat ideal, gaya-gaya yang timbul akibat pengunyahan dapat disalurkan lebih baik, ginggival sulcus lebih sehat (tidak tertutup/teriritasi landasan), menyalurkan panas lebih cepat. 
Kekurang bahan logam adalah kekurangan estetik bila logam terlihat dan biaya pembuatan lebih tinggi.

\section{KESIMPULAN}

Perbedaan GTSL bahan akrilik dengan logam dapat dilihat pada table berikut :

\begin{tabular}{|l|c|c|}
\hline & Akrilik & Logam \\
\hline Proses pembuatan & Mudah & Sukar \\
\hline Kekuatan & Kurang & Kuat \\
\hline Penghantar panas & Kurang & Baik \\
\hline Menyerap air & Dapat & Tidak dapat \\
\hline Perubahan warna & Dapat & Tidak dapat \\
\hline Luas basis & Luas & Tidak Luas \\
\hline Biaya & Murah & Mahal \\
\hline
\end{tabular}

\section{DAFTAR PUSTAKA}

Academy of Prosthodontics, 1999, The Glossary of Prosthodontic Terms, Edition 7, Mosby Inc, Universitas Michigan.

Carr, AB, McGivney, G.P, and Brown, DT, McCracken's Partial Removable Prosthodontics, 11th ed, Elsevier Mosby

Dentamedicacenter.com 2012, J1. A. P Pettarani No. 21B Makasar 90232

Herijulianti, Eliza dkk. 2002. Pendidikan Kesehatan Gigi. Jakarta:EGC

Nallaswamy D. Textbook of Prosthodontics. New Delhi: Jaypee Brothers, Medical Publishers; 2003: p. 266-7

Rachman A, Prosiding, PERIL IKG 25-26 Mei 2007, Disain Gigi Tiruan Sebagian Lepasan Frame: Kasus Berujung Bebas, Fakultas Kedokteran Gigi, Universitas Padjadjaran, Bandung

Ramadhan, Ardyan Gilang. 2010, Serba Serbi Kesehatan Gigi dan Mulut, Jakarta http://www.persify.com/id/perspectives/medicalspecialty/prostodonsia- -911000103111 